\title{
Legal Liability of Doctors on the Disclosure Medical Secrecy for Covid-19 Patients in the Pandemic Era
}

\author{
Jaufan Fata Almadani, Andika Persada Putera, Yulianto \\ Program Studi Magister IImu Hukum, Fakultas Hukum, Universitas Hang Tuah, Surabaya
}

Published: 02/03/2021

How to cite (in APA style):

Almadani, J. F., Putera, A. P., \& Yulianto. (2021). Legal Liability of Doctors on the Disclosure Medical Secrecy for Covid19 Patients in the Pandemic Era. Jurnal Hukum Prasada, 8(1), 1-7. doi: https://10.22225/jhp.8.1.2912.8-20

\begin{abstract}
The Covid-19 outbreak is a disease that attack countries around the world, no exception in Indonesia. The discourse of revealing the secrecy of positive Covid-19 patient medicine raises pros and cons in society. This study aims to analyze the concept of medical secrecy according to statutory regulations and legal liability of doctors in revealing medical secrecy in the pandemic era. This study uses a normative juridical method with a statutory approach, and a conceptual approach. The source of data collection consists of primary, secondary, and tertiary legal material. The results of the research show that medical secrecy is confidential individual right. The identity of Covid-19 patients can be accessed in a limited manner by authorized institutions and used proportionally and appropriately for the benefit of handling the Covid-19 outbreak. In order to anticipate an increase in Covid-19 transmission, the practice of using patient personal data is implemented by several countries according to principles proporsionalitas, necesssitas and purposive limitation.
\end{abstract}

Keywords: Covid-19; Legal Liability; Medical secrecy; Personal Data Protection; Statutory Regulation

\section{INTRODUCTION}

The Covid-19 outbreak is a disease disaster that attacks countries around the world, including Indonesia. This disease was first identified in the territory of the Republic of Indonesia for the first time at the end of March 2020, where two residents from Depok City, West Java became the first subjects to contract the disease. The transmission of two positive Covid-19 patients began when one of them made physical contact with a Japanese citizen who turned out to be positive for Covid-19 during an examination in Malaysia. Meeting between Patient 01 and Japanese Nationals at a dance on Valentine's night at the Amigos Club, Jakarta (Azizah, 2020). It turns out that the Japanese citizen had contracted Covid-19 and transmitted it to Patient 01, then Patient 01 also transmitted the Covid-19 virus to his mother (Patient 02). Finally, both of them underwent a test; as a result tested positive and had to be isolated at the Sulianti Saroso Hospital.

President Joko Widodo announced the first case of Covid-19 in Indonesia on March 2, 2020 (Bustan, 2020). Since the first case identified by the Government, the spread of the Corona virus in a number of regions in Indonesia has begun to be revealed and has even begun to show an increase. Based on data released by the Ministry of Health of the Republic of Indonesia on 1,133,758 cases with 62,784 deaths (CFR 5. 5\%) in 204 Affected Countries (Kementerian Kesehatan RI, 2020). Whereas for the Indonesian territory as of April 2020, there were 1,242 people who were examined with the results of the examination, namely 8,969 negative people (including ABK World Dream and Diamond Princess), and 2,273 confirmed positive cases of Covid-19 (164 recovered and 198 died) (Kementerian Kesehatan RI, 2020).

In the midst of the process of handling and preventing the global Covid-19 pandemic, the opening of the identity of a positive Covid-19 patient has become a polemic in the public and policy makers. Some people think that the disclosure of personal data including a history of 
positive COVID-19 patients is considered capable of being an effort to prevent greater transmission. On the other hand, it has the potential to create discrimination and the opportunity to identify the patient's family and those closest to him. Observing this situation, the Institute for Community Studies and Advocacy; called as ELSAM, assessed that every action of processing personal data for Covid-19 patients, especially disclosure them, must correspond to the principles of protecting personal data and in line with medical ethics (Lembaga Studi dan Advokasi Masyarakat (ELSAM), 2020).

In the context (principles and regulations) of personal data protection, including in the Personal Data Protection Bill, health data is included in the category of sensitive data, whose management requires a more careful protection mechanism by ensuring its accountability. Based on the records of ELSAM (2016), of the 32 laws that regulate the protection of personal data, 5 of them are related to the health sector, including access to health data, namely: the Medical Practice Law, the Health Law, the Hospital Law, the Mental Health Law, and the Health Manpower Act. In Article 57 paragraph (2) of the Health Law it is stated that the exception in data protection, one of which can be done is in the interests of the community. However, of course it must meet the principles of necessity and proportionality, meaning that it must be done strictly and in a limited manner (Lembaga Studi dan Advokasi Masyarakat (ELSAM), 2020). The confidentiality of patient medical records is regulated in Regulation of the Minister of Health No. 269/MenKes /Per/III/2008 concerning Medical Records, which obliges all health service providers to maintain the confidentiality of patient medical records. In Article 10 (2) of the regulation it is stated that opening a medical history is possible for the benefit of health, fulfilling requests from law enforcement officials, patients themselves, and for research or educational purposes as long as it does not mention the patient's identity.

In the context of handling COVID-19, every practice of collecting personal data for a person, including tracking location data, must be carried out in accordance with the principles and laws of protecting personal data. The reason is, the potential for violations is very likely to occur with the implication of discrimination and exclusivity (exclusion) against the parties concerned, including increasing the situation of excessive fear for the public. The cause of data leakage on Covid-19 patients can actually be done by several parties such as doctors, the Covid-19 handling group, data managers, and even hackers. However, this study limited the leakage of data by doctors. This study aims to analyze the concept of medical secrecy according to statutory regulations and legal liability of doctors in revealing medical secrecy in the pandemic era.

\section{METHOD}

\section{The Type and Approach of Research}

This researcher uses a normative juridical research method, in the form of a normative legal study, which examines the law that is conceptualized as a norm or rule that applies in society, and becomes a reference for everyone's behavior (Ishaq, 2017). Normative legal research is legal research that is carried out by examining library materials or secondary data (Soekanto \& Mamudji, 2015). According to Terry Hutchinson in Marzuki (2009) that doctrinal research is research that provides a systematic explanation of the rules governing a particular legal category, analyses the relationship between regulations, explains areas of difficulty and predicts future development.

This study uses a statutory approach and a conceptual approach. The statutory approach is carried out by examining statutory regulations related to the main research problem. The conceptual approach is carried out by examining the views and doctrines that develop in legal science and are used as a foundation in legal argumentation when resolving legal issues at hand.

\section{Legal Materials}

This research is a research that collects data and examines various data sources consisting of primary, secondary and tertiary legal materials which include: 
a. Primary Legal Material are legal materials that are legally binding in the form of the Medical Practice Law, the Health Law, the Hospital Law, the Law on Health Workers, the Law on Contagious Disease Outbreaks, and the Indonesian Medical Code of Ethics.

b. Secondary Legal Materials are in the form of all publications on law related to research studies such as text books, legal dictionaries, legal journals and comments on court decisions.

c. Tertiary Legal Materials, namely legal materials that provide instructions and explanations for primary and secondary legal materials such as encyclopedias, articles from official sources and non-legal materials that have relevance to the problem to be studied.

\section{Collecting and Managing legal materials}

The method of collecting and managing legal materials in this study is by using literature study, namely the technique of collecting literature related to this research. This study uses qualitative data analysis which includes the activities of classifying legal materials, editing, presenting the results of the analysis in narrative form, and drawing conclusions.

\section{Analysis of Legal materials}

Analysis of legal materials carried out is normative analysis. Analysis of legal materials in the study was carried out in a qualitative and comprehensive analysis. Qualitative analysis means describing legal materials in a quality manner in an orderly, coherent, logical, non-overlapping and effective sentence form, thereby facilitating the interpretation of legal materials and understanding the results of the analysis. Comprehensive means that the analysis is carried out in depth and from various aspects according to the scope of the research.

\section{RESULTS AND DISCUSSION}

\section{The Concept of a Medical Secrecy according to the Statutory Regulations}

The disagreement regarding the disclosure of public information by freeing the right of access to information on the identity of positive COVID-19 patients has become a legal issue during this pandemic. A request to reveal data on positive COVID-19 patients totally, some groups considered this was necessary in order to curb the rate of transmission to the community. The disclosure of medical secrecy belonging to Covid-19 patients is expected that the public will be able to find out about the subject, domicile location and history of social interactions of patients or suspected positive COVID-19 patients. Proponents of disclosing medical record data have the view that transparency is needed as a means of early protection against the risk of transmission by limiting distance.

The opening of patient medical secrecy to the general public in the midst of the COVID19 pandemic has led to negative stigmatization for sufferers and their families which will certainly have severe psychosocial impacts, such as discrimination. Therefore, it is necessary to have a good understanding of the ethical and legal foundations of medical secrecy, including opening medical secrecy to medical and health circles.

\section{a. Disclosure of medical secrecy to the patients and public}

As stated in the Decree of the Medical Ethics Honorary Council No. 015 / PB / K.MKEK/ 03/2020 concerning Medical Ethics Fatwas, Health Policies, and Research in the Context of the COVID-19 Pandemic, that medical secrecy related to the interest of collecting information can be revealed in certain circumstances (Kusmaryanto, 2018). The universal participation of the public in the collection of health surveillance information, of course, must be followed by reciprocity from the government in the form of implementing "transparent" surveillance. Transparent in this case means that patients must also be aware of what information they provide, for what, and the possibility of disclosing information to the third parties. In addition, in line with Article 154 of Law Number 36 Year 2009 concerning Health, transparency also refers to the government's obligation to announce the results of surveillance periodically, 
namely announcing the type and spread of disease, including areas with potential for infection. This is important for the protection of the right to public health as a whole in all regions. It is important to remember that an action is considered good if it has good intentions, is done in a good way, and is done at the right time, place and situation.

World Health Organization (WHO) recommends rapid data sharing related to public health emergencies. In an epidemic condition, which is a situation full of uncertainty and instability, periodic data sharing is crucial and urgent. Data in this regard includes health surveillance, clinical research studies, epidemiology, qualitative and environmental studies. Every party that plays a role must work together in sharing relevant and accurate data for the prevention of the epidemic. The involvement of large amounts of data requires States to review laws and policies related to data sharing and their confidentiality. For the public, periodic information sharing in a transparent manner can counter misinformation, calm panic, restore public confidence, and encourage public assistance in an ongoing crisis - in other words the urgency of sharing periodic data can generate effective responses.

Apart from the Health Law, there are several other regulations that support transparency of information to the public in epidemic conditions, namely Article 12 of the Information Commission Regulation Number 1 of 2010 concerning Public Information Service Standards obliging public bodies that have the authority to publish information that can threaten the livelihoods of many people, including information related to epidemics and outbreaks. Of course, this is also supported by the right to health which has been guaranteed in Article 4 of the Health Law which reads, "Everyone has the right to health." What is meant in this article is the right to obtain health services from health service facilities in order to realize the highest degree of health. As well as Article 9 paragraph 3 of Law Number 39 Year 1999 concerning Human Rights.

Through this, the disclosure of medical secrecy is not only related to disclosing information to the public, but is also related to surveillance purposes. Referring to the MKEK Decree regarding the ethical fatwa of COVID-19, the disclosure of medical secrecy is limited to things that are relevant to tracing transmission, without revealing the patient's full identity. Of course, the disclosure of identity obtained exception for some figures with strong legislation and ethical reasons. Regarding research and surveillance, the sharing of necessary data must also protect detailed medical secrecy and is limited to its use in relevant and approved activities.

\section{b. Protection of medical secrecy in pandemic condition}

The secret of medicine binds the relationship between doctor and patient based on various regulations. The Indonesian Doctor's Oath item 4 states that, "I will keep everything I know secret because of my profession". This is confirmed by the 2012 Indonesian Code of Medical Ethics in Article 16 which states "Every doctor is obliged to keep everything he knows about a patient secret, even after the patient dies." This code of ethics is one of several requirements of the medical profession, which is to keep everything about patients confidential (Sudjana, 1993). In line with Law no. 29 of 2004 concerning Medical Practice article 48 paragraph 1 which states "Every doctor or dentist in carrying out medical practice is obliged to keep medical secrecy." Medical secrecy can only be disclosed if there are strong ethical reasons and when exercised with great care. Supported by the explanation in Article 16 paragraph 3 of the Code of Medical Ethics that, "A doctor may not use his patient's secrecy to harm the patient, family or close relatives by disclosing them to third parties or unrelated." The obligation to protect secrecy is also in line with the basic principles of autonomy and beneficence bioethics. The principle of autonomy applies because generally the safeguarding of secrecy is what the patient wants and the beneficence refers to do a good thing for patient's interest.

Referring to the Decree of the Medical Ethics Honorary Council Number 015/PB/ K.MKEK/03/2020 concerning Medical Ethics Fatwas, Health Policies and Research in the Context of the COVID-19 Pandemic, the identity of patients, with or without symptoms, and positive cases must still be protected. In certain circumstances, information can be disclosed, limited to the initials name, gender, brief health status (death, clinically critically severe, or 
recovered), age and chronology relevant to transmission tracing. As for other in-depth clinical information, which is of no broad public health interest, such as detailed health status, comorbidities, and management should not be disclosed. However, returning to the exception to the provisions of the prevailing laws and regulations, including the opening of the names of public officials and the names of medical personnel who are victims can be awarded by the medical profession and the State.

Thus, the disclosure of medical secrecy collected during an outbreak (including name, address, diagnosis, family history, etc.) without the patient's consent could put the individual concerned at risk. Therefore, World Health Organization (WHO) suggests that despite the need for the country to control the outbreak, the state must also ensure adequate protection against risk. This can be done by ensuring the law of confidentiality of information on surveillance activities and the use of limited information only for the purpose for which it was collected. The use and sharing of information for activities other than surveillance or research that are less related, require submission of ethics to the committee concerned. For surveillance purposes, disclosure of patient identities to a certain extent is acceptable, but for research it is not acceptable because there is no reason whatsoever requiring the disclosure of the identity of the research subject. All clinical data may be disclosed, except the identity of the research subject.

Based on the description above, the researcher concluded that medical secrecy are the privacy rights of everyone, secrecy that must be kept secret by doctors in health care facilities. As stated in the Regulation of the Minister of Health (PMK) No. 269 / MenKes / Per / III / 2008 concerning Medical Records, obliging all health service providers to maintain the confidentiality of patient medical records. This obligation is a moral obligation based on the norms of decency, medical secrecy is not absolute and can be disclosed in certain circumstances, namely at the request of the patient, due to compulsion, complying with statutory regulations, existence of position orders and public interest while still adhering to the basic principles of bioethics, namely autonomy and beneficence.

\section{Medical secrecy in Medical Record}

Medical Records according to Minister of Health Regulations No. 269 of 2008 is a file containing notes and documents regarding patient identity, examination, treatment, actions and other services that have been provided to patients. Medical Records are included in medical secrecy as described in Law No. 29 of 2004 concerning Medical Practice. Medical secrecy include data on (1) patient identity, (2) patient health data including results of history taking, physical examination, supporting examinations, diagnosis, treatment and / or medical action. Article 48 states that in carrying out medical practice, every doctor or dentist is obliged to keep medical secrecy. Medical secrecy can be disclosed only for the benefit of the patient's health, fulfilling the demands of law enforcement officials, and at the request of the patient himself.

In Articles 3 and 5 of the Minister of Health Regulation Number 4 of 2018 concerning Hospital Obligations and Patient Obligations, it is stated that there is an obligation for hospitals to provide correct information about services to patients. Article 2 of the Law on Public Information Disclosure states that every public information is open and can be accessed by every user of public information, unless certain information is strict and limited. Exempted public information that is confidential in accordance with the law. Information that has consequences if closed and disclosed to the public must be carefully considered the consequences for the greater interest.

Notwithstanding, there has always been a balance between individual and collective rights, public health legislation exerts great power in the context of a public health emergency. Some ethicists and policymakers have proposed that individual rights, in particular the right to privacy of one's personal health information, should be defeated in the collective interest of society when this is seen to help prevent a more serious spread to the general public. Information about infectious diseases is public information that is open and accessible to the public, but if there is confidential information which, if disclosed, can have negative 
consequences, there must be certain considerations in accordance with statutory regulations. In other words, if the patient's medical record data is revealed, it will certainly contradict the medical record regulations as described in the Minister of Health Regulation Number 36 of 2012 concerning Medical Secrecy, which in principle in certain cases can be disclosed but limited as needed. This is formulated in Article 5, while Article 6 states that the disclosure of medical secrecy for the benefit of patient health is carried out with the patient's consent either in writing or an electronic information system. However, Article 9 states that the disclosure of medical secrecy can be carried out without the patient's consent in the interests of upholding ethics or discipline and the public interest. Further, the disclosure of medical secrecy in the framework of the public interest was carried out without revealing the patient's identity. The intended public interest is medical audits, threats of extraordinary events or epidemics of infectious diseases, education, and threats to the safety of other individuals or the community. Disclosure of medical secrecy for the benefit of information on extraordinary events or outbreaks of infectious diseases and threats to the safety of others, then the patient's identity can be disclosed only to institutions or parties authorized to carry out follow-up actions.

Based on the description above, it can be concluded that the right to public information in relation to health services is the right of every person/community to obtain information from the government as the person responsible for ensuring the right to healthy life for everyone. In order to realize the right to health information, the government has developed a health information system. The development of a health information system is also carried out so that access rights to health services can be fulfilled, the quality of services can be monitored, so that a good health degree is achieved.

\section{Right to Medical Secrecy}

Discussion of medical confidentiality (medical secrecy) cannot be separated from the discussion about informed consent and medical record. In health care, this is known as the secret medical trilogy concept. The definition of this medical secret trilogy arises because in every health care effort there are three important things that are interrelated between one action and another. Informed consent is the patient's right to give consent for medical action against him. Patient rights that originate from human rights, namely the right of self determination.

The background of the informed consent procedure in health services, which involves a relationship between a doctor (health worker) and the patient or commonly known as a therapeutic relationship, based on the reason: the doctor-patient relationship is based on trust (Yunanto \& Helmi, 2010); the existence of the right to autonomy or the right to determine himself over himself; there is a contractual relationship between doctor-patient (Mertokusumo, 2005). Meanwhile, the purpose of informed consent is to provide legal protection to both patient and doctor who perform medical procedure (Prananda, 2020). In principle, in an informed consent procedure, the patient's right begins with the provision of information from the doctor who provides medical services and ends with the patient's consent for medical action.

Patient health data is recorded in a file called a medical record which has confidentiality value. The provisions on medical records are formulated in the Minister of Health Regulation Number 269 of 2008. According to the Minister of Health, a medical record is a file containing notes and documents including the patient's identity, examination results, treatment that has been given, as well as other actions and services that have been provided to patients. Notes are writings made by doctors or dentists regarding actions taken to patients in the context of health services. Furthermore, it is stated that the form of a medical record can be in the form of a manual, which is written completely and clearly or in electronic form according to the provisions. Medical records consist of patient data records performed in health services. These records are very important for patient care because complete data can provide information that determines various decisions whether treatment, treatment, medical action and others. Doctors or dentists are required to make medical records in accordance with applicable regulations. 
The guarantee for the protection of the right to medical records is regulated in Article 79 letter $b$ of the Medical Practice Law in the formulation of criminal sanctions which states that, "shall be punished with imprisonment for a maximum of 1 (one) year or a maximum fine of IDR. 50,000,000.00 (Fifty Million Rupiah), every doctor or dentist who deliberately does not make medical records as referred to in Article 46 paragraph (1)." (Note: the sanction of imprisonment was declared not legally binding through the Judicial Review of the Constitutional Court in July 2007).

The description above emphasizes the relationship between medical information, medical records, and medical secrecy. A doctor is obliged to keep secret everything that is conveyed by his patient, whether conveyed consciously or unconsciously and everything that is known by the doctor when treating the patient; this is what is called the medical secrecy. The framework of thinking about medical secrecy arises first of all from the professional obligation to keep confidential information obtained in the course of the profession. This obligation is the main obligation of several obligations of doctors (Hatta, 2010). Information obtained by professionals in carrying out a profession is known as a secret position, while information obtained by a doctor in carrying out his profession is known as a medical secrecy.

The legal basis for regulating medical secrecy is regulated in the Medical Practice Law and Law No. 36/2009 on Health (Health Law). In the provisions of Article 48 of the Medical Practice Law, it is stated that every doctor or dentist in carrying out medical practice is obliged to keep medical secrecy. Medical secrecy can only be disclosed for the benefit of patient health, fulfilling requests from law enforcement officials in the context of law enforcement, patient requests, or based on statutory provisions. It is stated that the nature of this confidentiality does not apply in the case of the statutory orders; court order; the license concerned; public interest; or interests of that person. Therefore, with the patient's consent, confidentiality, one of which is medical records, can be disclosed (Haryanto, 2015).

Thus, it can be concluded that the right to medical secrecy cannot be separated from the medical secrecy trilogy, namely the Medical Consent, Medical Record and Medical Secrecy. Informed consent itself provides legal protection, both for patients and doctors who perform medical actions. The contents of the medical record belong to the patient, while the documents belong to the health service facility. In the provisions of Article 57 of the Health Law, it is stated that everyone has the right to confidential personal health conditions that have been disclosed to health service providers.

\section{c. Provisions for the Disclosure of Medical Secrecy for Covid-19 Patients Abroad}

The spread of the Coronavirus disease throughout countries in the world has prompted several heads of government to adopt unconventional policies. A number of policy breakthroughs have been launched by each country to deal with Covid-19 transmission. One of the controversial policies is the access of using personal data that risks violating the privacy and basic rights of citizens.

Privacy enforcement authorities generally support a pragmatic and contextual approach in dealing with emergencies caused by Covid-19 while still paying attention to proportionality and respect for the principles of public privacy. The use of partial data privacy aims to assess and enhance the capacity of the health care system and evaluate the effectiveness of containment and mitigation policies that limit the movement of individuals. This poses new challenges to privacy governance and security; for example, personal contact tracing is used to provide important information to limit the spread of virus. However, on the one hand, it has the potential to lead to mass collection and sharing of personal data, curbing individual freedoms and disrupting people's democratic rights.

In the practice of countries such as America, UK and Singapore, third of them have a strong legal basis in the form of a strong Personal data protection law. So, even though there is a policy to access personal data of patients who are suspected or have been infected with COVID-19 (Contact Tracing), the scope of personal data traced includes activity track records that have a correlation with transmission and locations visited for approximately 14 days without exposing patients' identities. This step is considered fair because the benefits can 
have a positive effect, namely suppressing transmission by providing information to the public that has the potential to have direct contact with patients. Even so, the dissemination of information and the status of a patient's medical record is still not permitted to be disclosed to the public, except with the explicit consent of the data owner and the vital interests of the data subject.

The Indonesian government particularly can adopt the practice of using personal data but it is based on the principles of protecting personal data, namely the principles of proportionality, necessities and purposive limitation. The principle of purposive limitation is a limit on the collection of personal data and the data must be obtained in a legal and fair manner, especially with the consent of the data owner (Munir \& et al., 2014). The content of personal data that has been collected can only be used on a limited basis in connection with the COVID-19 response policy. With a note, got the consent of the patient concerned without publishing a personal profile.

\section{Legal liability of Doctors on Dislosure Medical Secrecy}

At first, various levels of society had demanded that the central government disclose data regarding the spread of COVID-19. However, the provisions stipulated in Law Number 14 of 2008 concerning Freedom of Information appear to be inconsistent with what the public demands. Article 17 a quo Law regulates the exclusion of information that may be disclosed to the public or the applicant. This article provides for the protection of personal secrecy which in that provision also regulates medical information. It was said that, "Public Information, if opened and provided to the Public Information Applicant, could reveal personal secrecy, namely:

a. History and condition of family members;

b. History, condition and treatment, physical and psychological health medication of a person;

c. A person's financial condition, assets, income, and bank account;

d. Evaluation results in relation to a person's capability, intellect, and recommendations;

e. Records concerning a person's personality related to the activities of formal education units and non-formal education units

Doctor is responsible for keeping and protecting all information related to medical secrecy and the confidentiality of patient medical records. The form of responsibility given is in the form of civil law, administrative law, and criminal law responsibility.

\section{a. Legal responsibility in the field of Criminal law}

The legal action that victims of Covid-19 and their families can take is through a criminal process. Criminal law is a law that regulates actions prohibited by law along with criminal sanctions that can be imposed on the perpetrator. It is hoped that law enforcement officials for everyone who spreads information that causes harm, and the negligence of doctors who do not keep patient data confidential is a criminal offense that can be prosecuted legally.

In the Indonesian legal system, a principle is known, namely the principle of legality (Machmud, 2008). This principle means that a criminal act or a criminal act or an act violates criminal law, only if an existing criminal provision determines that the act is a criminal act. This is stated in Article 1 paragraph (1) of the Criminal Code, which reads, "No act can be punished unless it is based on the criminal rules in legislation which already existed before the act was committed." The word "except" in Article 1 paragraph (1) of the Criminal Code contains restrictions on criminal acts, not every act can be criminalized even though ethically it may conflict with social morals or the customary law of a society (Yunanto \& Helmi, 2010). In the context of medical practice, the element of a criminal incident begins when a doctor commits an act in accordance with the prohibitions stated in the Law which is punishable by punishment and the wrongdoing can be accounted for because it is contrary to the prevailing law in society, the doctor concerned can be subject to criminal law.

The obligation to keep medical confidentiality is listed twice in Law No. 29 of 2004 concerning Medical Practice, namely Article 48 paragraph (1) to paragraph (3) and Article 51 
letter (c) of the Medical Practice Law. As for the contents of Article 51 letter (c) of the Medical Practice Law, namely "Keep everything he knows about the patient a secret, even after the patient dies."

This obligation may be waived under Article 48 paragraph (2) of the Medical Practice Law which allows medical secrecy to be disclosed for the following matters.

1. For the benefit of the patient's health, the doctor may explain the patient's condition to his family, for example: a patient with advanced cancer which is difficult to cure, may not be explained to the patient concerned. In this case, the patient's family may be notified so that they can prepare themselves in case of treatment or unwanted things occur.

2. To meet the demands of law enforcement officials in the context of law enforcement. In this case, a doctor may reveal his medical secrecy, for example: a criminal offender is consulted with a doctor to determine whether or not the perpetrator is legally responsible. In Article 44 paragraph (1) Kitap of the Criminal Code (KUHP) it is stated that, "There can be no punishment whoever commits an act that cannot be held accountable to him, because his mind is less than perfect or sick of his mind changes."

According to article 44, a person who cannot be punished is a person who cannot be held accountable for his actions because:

1. People who are less than perfect in their minds, for example: idiots, deaf-blind, mute from birth, mentally retarded, and people who are less than perfect in mind power, other mental powers so that their minds remain as immature children. This disease of less than perfect sense is usually a defect from birth.

2. Pain changes its mind, for example insanity, hysteria, epilepsy and so on caused by illness. Changes in reasoning in this group are usually caused by a disease that the person is suffering from, not a congenital disease.

In the determination of less than perfect sense or sickness, doctors are usually allowed to examine and provide information in order to assist law enforcement (Isfandyarie, 2006).

3. At the request of the patient himself.

4. Based on statutory provisions.

With the provisions that have been elaborated in accordance with Article 48 paragraph (2) of the Medical Practice Law, the act of a doctor who discloses a secret outside the four reasons will be subject to a criminal sanction of 1 (one) year in prison or a maximum fine of $\mathrm{Rp} \mathrm{50,000,000} \mathrm{(fifty} \mathrm{million} \mathrm{rupiah)} \mathrm{based} \mathrm{on} \mathrm{Article} 79$ point (c) of Law No. 29 of 2004 concerning Medical Practice. In addition, the provisions regarding the obligation to keep medical secrecy are contained in Article 322 of the Criminal Code which regulates that:

a. Anyone who deliberately discloses a secret which according to his position or occupation, both current and former, is obliged to keep it, shall be punished by a maximum imprisonment of nine months or a maximum fine of nine thousand rupiahs.

b. If the crime was committed against a certain person, then that act can only be prosecuted upon complaint by that person.

However, with regard to criminal law sanctions, in certain cases doctors are faced with a dilemma in relation to Article 322 of the Criminal Code. In this case, he was presented as a witness with the obligation to reveal medical secrecy in a court session. The provisions of Article 322 of the Criminal Code prohibit doctors from disclosing medical secrecy (doctors are passive), on the other hand Article 224 of the Criminal Code requires doctors to testify (doctors are active). This is supported by Hanafiah \& Amir (2017) statement that in court all secrecy in the form of medical records can be given. 
To know the limits of a doctor's legal obligation to keep the secret of his profession with the legal obligation to testify lies in the hands of a judge who has the authority to determine whether or not it is legal based on Article 170 of the Criminal Code. The limitations are:

1. In the event that a doctor is present in court as an expert witness without any connection with the party in the case, the doctor is free to provide information in accordance with his expertise, without appointing a specific person.

2. If a doctor appears in court, as the party sued by his patient, the doctor can reveal things that are known about the secret of the patient's illness.

3. If a doctor is asked by a patient to be a witness for a patient who has a case with another party, then the doctor may reveal the confindentiality that are known to the patient, because the patient is deemed to have exercised the right of waiver or the doctor can also refuse the patient's request through the right to refuse disclosure (verschongsrecht).

\section{b. Legal Responsibility in the Field of Civil Law}

Doctor is considered to be responsible in the field of civil law if the doctor does not carry out his obligations (broken promise), that is, does not give his performance as agreed and because of acts against the law (Astuti, 2009). According to Isfandyarie (2006) verification of civil law as follows.

1. If a doctor is sued by a patient for committing medical malpractice, then usually the basis for the demands submitted by the patient to the doctor, they are:

a) Doctor accused of default (Broken promise), prosecuted under Article 1239 BW;

b) The doctor was accused of committing an illegal act, prosecuted under Article $1365 \mathrm{BW}$;

c) The doctor was accused of negligence so as to result in loss, was prosecuted under Article $1366 \mathrm{BW}$; and

d) The doctor was accused of neglecting his job as a person in charge, prosecuted under Article 1367 BW

2. In facing the patient's demands or lawsuit, the patient must prove the basis of his claim or lawsuit as regulated in Article 1865 BW which reads, "Anyone who argues that he has something right, or in order to assert his own rights or deny the rights of others, refers to an event, is required to prove the existence of the right or event."

From Article $1865 \mathrm{BW}$ regarding the evidence above, it can be interpreted that if a patient sues or sues a doctor, he must be able to prove the accused doctor's mistake or negligence. According to Suryadhimirtha (2011), lawsuit based on default in the engagement law. Default means that an agreement is not fulfilled by one of the parties (the debtor) because of an element of fault. The fault itself can be 1) Deliberate, that is an act that causes the obligation not to be fulfilled is desired or known by the debtor and 2) Negligence, the person who commits the act only knows that there is a possibility that the adverse consequences will arise

The result of a lawsuit based on default is the obligation to provide compensation as stipulated in Book III of the Civil Code. In a therapeutic transaction, a suit based on default can be filed if a health worker practicing independently or an institution (hospital) has promised to provide medical services or a therapeutic transaction, but later it turns out that he did not carry out the promise, even though he was not in a state of compel.

A lawsuit based on an unlawful act by a patient can be made based on the provisions of the Health Law and the provisions stipulated in the Civil Code. The difference with a suit based on default is that it is based on a therapeutic transaction. Actions against the law other than one's actions are contrary to the Law, also if someone does or does not act which:

1. Infringe the rights of others

2. Contrary to the legal obligation of the person who acts

3. Contrary to decency 
4. Not in accordance with the propriety and accuracy of self or other people in social life in society

In a lawsuit violate the law, what is meant by loss also includes material losses and immaterial losses as applicable in a lawsuit based on default. With the aforementioned provisions, when compared to a lawsuit based on an unlawful act, it is much broader than a default because the default is an agreement (Suryadhimirtha, 2011). Thus, if doctor violate the law by not carrying out their obligations in keeping the medical secrecy of Covid-19 patients as agreed, they will be subject to civil sanctions. A lawsuit can not only be directed to the doctor, but also to the people who are responsible for the actions committed by those under his care. The hospital can be sued to be responsible for illegal acts committed by health workers who work in the hospital.

\section{c. Legal Responsibilities in the Field of Administrative Law}

The enforcement of Administrative law is carried out due to administrative violations by the medical or dentistry profession, as well as against violations of medical ethics. In State Law, the use of administrative sanctions is the application of governmental authority, where this authority comes from written and unwritten State Administrative law rules. Sanctions are an important part of every statutory regulation, even J.B.J.M. ten Berge stated that sanctions are the essence of enforcement of the State Administrative Law (Sujamto, 1996).

According to J.J. Oosternbrink that administrative sanctions are sanctions that arise from the relationship between the Government and citizens which are implemented without intermediary third parties or without intermediary powers of justice, but can be directly implemented by the administration itself. When citizens neglect obligations arising in administrative relations, the opposing party (namely the government) can impose sanctions without the intermediary of a judge. This means that sanctions can be implemented by the head of the work unit as a State administrative official who is given by the existing laws and regulations.

Administrative sanctions are an important closing part of state administrative law regulations. Sanctions are used so that the obligations and prohibitions for the community as outlined in administrative law regulations can be obeyed by the community. Basically, to find out if there was a violation of medical ethics and / or administrative violation when the research was started by the medical and dentistry professional organization (Machmud, 2008).

On the violation of medical ethics or the institution that can give sanctions is the Medical Ethics Council (known as MKEK). In Law No. 29 of 2004 concerning Medical Practice, which is called MKEK, is the Honorary Council of Indonesian Medical Disciplines (Known as MKDKI) who receives complaints and has the authority to examine and decide whether or not a doctor has committed a mistake for violating the application of medical disciplines and the application of sanctions. The content of Article 69 of Law No. 29 of 2004 concerning Medical Practice is:

1. The decision of the Indonesian Medical Discipline Honorary Council is binding on doctors, dentists and the Indonesian Medical Council.

2. The decision as referred to in paragraph (1) can take the form of being declared innocent or imposing disciplinary sanctions.

3. The disciplinary sanction as referred to in paragraph (2) can be in the form of

a. Giving written warning;

b. Recommendation for revocation of registration certificate or license to practice; and / or

c. Obligation to attend education or training in medical or dental educational institutions

In Law No. 36 of 2009 concerning Health, it is explained about the authority of the Minister of Health in providing administrative action against health workers who commit violations. The article 188 of Law No. 36 of 2009 on Health is as follows: 
1) The Minister can take administrative action against health workers and health service facilities that violate the provisions stipulated in this Law.

2) The minister may delegate the authority as meant in paragraph (1) to non-ministerial government agencies, to provincial or regency or city offices whose main tasks and functions are in the health sector.

3) Administrative measures as intended in paragraph (1) can be in the form of (a) written warning and (b) Revocation of temporary or permanent permits.

4) Further provisions regarding the procedure for administrative action as referred to in this article shall be regulated by the Minister

Based on the regulations described above, if the medical secrecy of Covid-19 patients are opened without permitted elements, doctors can be subject to administrative sanctions such as written warnings, required to attend further education, revocation of practice licenses, postponement of periodic salary increases, demotion and so on.

\section{CONCLUSION}

Based on the results of the research that has been done, the researcher can conclude that:

1. Medical secrecy is the privacy right of everyone, secrecy that must be kept confidential by doctors in health care facilities, this obligation is a moral obligation based on the norms of decency, medical secrecy is not absolute and can be disclosed in certain circumstances, namely at the request of patients, because coercion, comply with statutory regulations, the existence of office orders and public interests.

2. In a certain situation that allow and oblige doctors to disclose medical secrecy, such as at the time of the Covid-19 outbreak which threatens public health and the most important thing is the doctor's duty to protect the community, whose position is superior to individuals. The disclosure of medical secrecy in the COVID-19 era in certain circumstances can be disclosed, limited to the initials of the name, gender, brief health status (death or clinically critically severe or recovered), the identity of Covid-19 patients can be accessed in a limited manner by authorized institutions and used proportionally and properly for the benefit of handling the COVID-19 outbreak. However, if the right to secret is violated by a doctor not in accordance with the applicable provisions, the offender has committed an unlawful act, namely a criminal offense, especially the provisions contained in Article 322 of the Criminal Code and law enforcement can be applied to the realm of criminal law. By civil law, patients who feel aggrieved can ask for compensation based on Article 1365 of the Civil Code. Meanwhile, in administrative law for doctors who violate a verbal or written warning, revocation of their license to practice, postponement of periodic salaries in accordance with Government Regulation of the Republic of Indonesia Number 10 of 1966 concerning Mandatory Keeping Medical Secrecy.

\section{REFERENCES}

Astuti, E. K. (2009). Transaksi Terapeutik (Dalam upaya pelayanan Medis di RS). Bandung: PT Citra Aditya Bakti.

Azizah, K. N. (2020). Kronologi 2 Pasien Pertama Virus Corona COVID-19 di Indonesia.

Bustan, M. T. S. (2020). Pasien Positif Covid-19 di Palu Kabur dari Rumah Sakit.

Hanafiah, M. J., \& Amir, A. (2017). Etika Kedokteran \& Hukum Kesehatan. Jakarta: Penerbit Buku Kedokteran.

Haryanto, E. Y. (2015). Kedudukan Rekam Medis Dalam Pembuktian Perkara Malpraktik di Bagian Kedokteran. LEX CRIMEN, 4(2).

Hatta, M. (2010). Kebijakan Politik Kriminal (Penegakan Hukum Dalam Rangka Penanggulangan Kejahatan). Yogyakarta: Pustaka Pelajar.

Isfandyarie, A. (2006). Tanggung Jawab Hukum dan Sanksi bagi Dokter (N. Y. Puspita, Ed.). Jakarta: Prestasi Pustaka.

Ishaq. (2017). Metode Penelitian Hukum \& Penulisan Skripsi, Tesis, Serta Disertasi. Bandung: Alfabeta. Kementerian Kesehatan RI. (2020). Tentang Data Persebaran Penyakit Virus Covid 19 per April 2020. Kusmaryanto, C. B. (2018). Bioetika. Yogyakarta: Buku Kompas. 
Lembaga Studi dan Advokasi Masyarakat (ELSAM). (2020). Perlu Kesetimbangan Perlindungan Privasi dan Kesehatan Publik dalam Penanganan COVID-19.

Machmud, S. (2008). Penegakan hukum dan perlindungan hukum bagi dokter yang diduga melakukan Medical Malpraktik. Bandung: Mandar Maju.

Marzuki, P. M. (2009). Penelitian Hukum. Jakarta: Kencana Prenada Media Group.

Mertokusumo, S. (2005). Mengenal Hukum Suatu Pengantar. Yogyakarta: Liberty.

Munir, A. B., \& et al. (2014). Data Protection Law in Asia. Hong Kong: Thompson Reuters Limited.

Prananda, R. R. (2020). Batasan Hukum Keterbukaan Data Medis Pasien Pengidap Covid-19: Perlindungan Privasi VS Transparansi Informasi Publik. Jurnal Law, Development \& Justice Review, Fakultas Hukum Universitas Diponegoro, 3(1).

Soekanto, S., \& Mamudji, S. (2015). Penelitian Hukum Normatif (Suatu Tinjauan Singkat). Jakarta: Rajawali Pers.

Sudjana, J. C. (1993). Peningkatan Peran PERHUKI oleh Peradilan Profesi. Yogyakarta: Kongres 111 PERHUKI.

Sujamto. (1996). Aspek-Aspek Pengawasan Di Indonesia. Makasar: Sinar Grafika.

Suryadhimirtha, R. (2011). Hukum Malpraktik Kedokteran. Yogyakarta: Total media.

Yunanto, A., \& Helmi. (2010). Hukum pidana Malpraktek Medic Tinjauan dan Perspektif Medikolegal. Yogyakarta: ANDI. 